\title{
Country of Origin, Price Consciousness, and Consumer Innovativeness at Food Service Outlets in Developing Markets: Empirical Evidence from Brands of Imported Beef in Vietnam
}

\author{
Thu Thanh $\operatorname{Tran}^{1}$, Masahiro Moritaka ${ }^{2} \&$ Susumu Fukuda ${ }^{2}$ \\ ${ }^{1}$ Graduate School of Bioresource and Bioenvironmental Science, Kyushu University, Fukuoka, Japan \\ ${ }^{2}$ Laboratory of Food Marketing and Distribution, Department of Agricultural and Resource Economics, Faculty of \\ Agriculture, Kyushu University, Fukuoka, Japan \\ Correspondence: Thu Thanh Tran, Laboratory of Food Marketing and Distribution, Department of Agricultural \\ and Resource Economics, Faculty of Agriculture, Kyushu University, Fukuoka, Japan. E-mail: \\ tranthanhthu308@gmail.com
}

Received: May 2, 2017 Accepted: May 22, 2017 Online Published: May 29, 2017

doi:10.5539/ijms.v9n3p50 URL: http://doi.org/10.5539/ijms.v9n3p50

\begin{abstract}
The aim of this study is to explore the importance of information about country of origin and price on consumer innovativeness toward beef at food service outlets in developing markets. We construct a structural equation model (SEM) and test our hypotheses using data from direct interviews with 480 customers at beef restaurants in Vietnam. The results from the SEM indicate that consumer need for newly imported beef is the reason of further requirements of information about country of origin and price of beef. To reduce the uncertainty of the new beef brands, consumers at food services outlet demand for details of country of origin. However, the need for information about country of origin, and price consciousness depend on the eating out experiences of the customers. Expertise consumers, who can use intrinsic cues such as beef flavor, beef tenderness, and beef marbling, indicate the significant innovative attitude toward new beef brands at food service facilities.
\end{abstract}

Keywords: price consciousness, country of origin, food service, consumer innovativeness, premium beef brand, SEM

\section{Introduction}

An increasing demand for animal products in emerging markets as a result of economic growth and urbanization (Gandhi \& Zhou, 2010; Fu et al., 2012) opens avenues for beef exporters in satisfying the emerging need of urban consumers in food service industry. Successful performances at the host markets require beef exporters to understand the features of users in the destination markets (Grunert, Bredahl, \& Brunsø, 2004). Since newness acceptance is slow in emerging markets, a relevant marketing communication with potential adopters could be in demand.

The Vietnamese market with a huge population of about 90 million people has been the promising market of many beef exporters. The imported beef brands such as Australian beef, American beef, and New Zealand beef dominated the beef market of major metropolitans as Hanoi City and Ho Chi Minh City. This tendency could be explained by some reasons from the demand side including the economic growth, the living standard improvement, and the cultural integration (Thu, Moritaka, \& Fukuda, 2016). The influences of Western life style and the appearance of Korean and Japanese cultures in Vietnam lead to the emerging need for high-grade beef with different taste from the local beef or the normal beef. However, the Vietnamese consumers face a lot of difficulties in making beef purchasing because of two reasons. The first is the weakness of Vietnamese government in conducting and controlling the flow of beef in the retail market, especially imported beef. The lack of not only quality management system but also the transparency in the country of origin and price in retail basements impose riskiness on consumers. The second is the opportunistic behavior of beef sellers in the Vietnamese market. Due to the shortage of government regulations for beef products, customers have depended on their senses or butchers' reputation to select beef. They have to bear a lot of riskiness such as unsafe beef, counterfeit beef, or beef with the disease. As results, the Vietnamese consumers tend to strongly consider the uncertainty from a new beef brand and remain high resistance toward the newly imported beef brands at the 
introduction stage.

The above context could be observed in other new opened markets in Asia as China, Thailand, or Philippine (Agriculture and Agri-Food Canada (2010)). The shortage of host market infrastructure makes the business performance of beef exporters riskier. Hence, increasing information about beef products could be a solution for the high resistance toward a new beef brands in the emerging markets.

In this paper, we investigated the impacts of information about the country of origin and price consciousness on consumer innovativeness toward new beef brands at food service outlets in the Vietnamese market. We selected country of origin and price as the major external cues since they were relevant in beef purchasing in developing markets. We hypothesized that the need for further information on country of origin as well as price consciousness was the derived need from the emerging need for newly imported beef due to the uncertainty related to the new beef brands. Eating experience was a major determinant of the concerns about the country of origin and price, as well as the consumer innovativeness toward a new beef brand. The availability of information about the country of origin and pricing would positively impact on the innovativeness for new beef brands through enhancing personal eating experiences.

We constructed this paper into seven parts. After the introduction of the research problem, we reviewed the relevant studies in the second part. Next, we presented the hypotheses and the structural equation model for testing these hypotheses. In the part of the methodology, we explained about the data collection and the variable measurement in the questionnaire. Next, we presented the results, the hypothesis testing, and discussed the findings. The paper ended with the conclusion and some managerial implications.

\section{Literature Review}

Consumer innovativeness, a core concept in marketing, was defined by Hirschman (1980) as "the consumer's tendency to adopt new products, ideas, goods, or services." Marketing scholars usually study consumer innovativeness with the diffusion process of innovation and the product life cycle to create marketing strategies for corporations and strategic business units. Empirical studies on this topic can be divided into three main research streams (Dobre, Dragomir, \& Preda, 2009). The first school of thought investigated the relationship between innovativeness and consumer personality. Alternatively, scholars tried to outline the makeup of innovators from psychological characteristics. For instance, Dobre et al. (2009) indicated that the person who adopted the first technological equipment was an opinion leader, risk tolerant, inside oriented, and independent from social norms. This individual also preferred obtaining information from mass media, was open minded, modern, and a high social status. The second stream focused on the demographic, social, and economic characteristics of innovation adopters. Adopters consist of consumers with high incomes, high levels of education, and high living standards (Labay \& Kinnear, 1981; Plummer, 1971; Robertson, 1967). Robertson's study (1967) examined the relationship between adoption and culture. One outstanding empirical study on this topic by Maitland (1999) discussed the impact of cultural factors on innovation. The five dimensions of cultural variables in that study included the degree of collectivism, the gender equality, the long/short term orientation, the risk tolerance, and the power gap.

Existing studies on consumer innovativeness have strongly emphasized on corporate strategies when launching an innovative product in markets. The success of innovation in a market depends on the knowledge gap between marketing agencies and potential adopters (Rogers, 2003), it is vital for marketers to understand the need for new product information from a consumer's viewpoint when making purchasing decisions in uncertainty. However, previous studies on this topic seem to be spare since scholars paid less attention to brand familiarity, price consciousness, self-confidence, and dogmatism (Arts, Frambach, \& Bijmolt, 2011).

Consumer beef purchasing behavior has been examined by a significant number of scholars since beef is an important grocery item. Most of the previous studies focused on the roles of sensory characteristics and extrinsic cues in consumer's evaluation of beef quality. Some previous scholars stated the importance of intrinsic cues such as tenderness, marbling, juiciness, and flavor in customer's beef quality estimation at retail grocery stores and restaurants (Bredahl, 2004; Bredahl, Grunert, \& Fertin,1998; Reicks et al., 2011). Other studies examined the role of the external cues, such as beef labeling that includes information about the country of origin (COO), price, traceability, and slaughter regimes. Both external and internal stimuli were considered as product attributes in a consumer's evaluation, emphasizing the expected quality, the actual quality, and the willingness to pay for a specific kind of beef (Bernués et al., 2003; Kim, 2008; Northen, 2000). However, previous studies on consumers' beef purchasing behavior have not considered the relationship between the need for such cues and consumer innovativeness toward beef.

Moreover, conclusions from previous research on beef purchasing behavior should be considered with caution, 
since most of them were conducted on consumers in the developed markets. Compared with the developed markets, the less-developed ones require different approaches, since the significant beef consumption in these markets has only recently emerged. To select beef, consumers in the less-developed markets generally utilize a butcher's reputation or their shopping experiences with retail basements. Low government regulation and the lack of transparency about origin of imported beef products in developing economies impose risks on consumers when buying beef at retail markets. In food service facilities particularly, beef origin is crucial in purchasing decision, because users enjoy cooked beef instead of buying fresh beef cuts. Hence, there is a need for further studies on the importance of country of origin in beef purchasing of consumers at food service outlets in less developed markets.

This paper investigated the relationship between consumer need for beef product information and consumer innovativeness toward the new beef brands at food service facilities in emerging markets through examining the new beef brands in the Vietnamese market. We attempted to contribute to the existing studies on consumer innovativeness, as well as beef purchasing behavior, with two main approaches. First, we focused on the role of consumer knowledge in consumer innovativeness by analyzing the impact of need for product information on innovative attitudes toward beef. Unlike previous studies on consumer innovativeness, we did not portray the adopters. We paid high attention to the question of how to motivate consumers' adoption processes at food service outlets via marketing communication. Second, we investigated how consumers in the less-developed markets use information cues to make purchasing decisions for a new brand of beef at food service outlets. The need for product information of a new beef was considered in relation to personal experiences in dinning out. We classified the personal experience at food service into two categories: general eating experience and professional eating experience. Regarding the professional experience, we followed previous studies on beef quality evaluation and used tenderness, flavor, and marbling content in measurement. In term of beef product information, we focused on information about country of origin and price as two external information cues for imported beef quality evaluation at food services outlets in the less developed markets since imported beef purchasing at food service has been the emerging trend in these markets.

\section{Hypotheses}

\subsection{The Need for New Products and Consumer Innovativeness}

Even though previous studies do not indicate the absolute concept of consumer innovativeness, this term is considered as intentional purchasing behavior (Midgley \& Dowling, 1978); early purchasing or variety-seeking behavior (Steenkamp, ter Hofstede, \& Wedel, 1999). These definitions describe the innovator as a consumer with early adoptive behavior for a new product than other consumers in the market. Since consumers are goal-seekers in the market, we might expect that consumers with high innovativeness have stronger interest into the innovation or high preference for the innovation. This statement could be reasonable in the following with Rorger (1983): adoptive behavior was the result of multi-stage process, which began from need or problem recognition.

Previous research stream on consumer innovativeness also classified adoptive behavior for product level and for a domain-specific level (Roehrich, 2004). In our study, we used domain-specific innovativeness, which measured the consumer intentional behavior toward new imported beef brands at food service. We hypothesized that high preference for new beef imported brands increases the consumer innovativeness toward newly imported beef brands.

H1: High preference for newly beef imported brands increases the consumer innovativeness toward new beef brands when dinning out at food service facilities in the Vietnamese market

\subsection{The Need for A New Product and the Need for Information about A New Product}

There are two major considerations when launching the innovation to the market: the uncertainty of the new product and the information about the new product. Due to the information asymmetry about the new product, the success of the innovation in the market depends on how marketing agencies can reduce the uncertainties of the new product in consumers' evaluation. At the early stage of the product lifecycle, increasing product information can enhance the consumers' awareness of a new product, reduce the ambiguity of product quality, and decrease the search cost of consumers in buying process. Literature on innovation adoption also indicated that consumer perception of innovation's characteristics was a driving force of adoption (Gatignon \& Robertson, 1985; Rogers, 2003). Hence, one might expect that the more preferable consumers for new products will require more information about new products.

Regarding the imported beef consuming at food service outlets in the emerging markets, we focused on the 
requirements of information about country of origin and price in innovativeness toward imported beef brands. The information about country of origin in our study served as an external cue for beef quality evaluation while price reflected how consumers' conscious concern about price information when buying beef at dinning out. Our term was different from previous studies on narrow definition of price consciousness as "the degree to which the consumer focuses exclusively on paying low prices" (Erickson \& Johansson, 1985; Tellis \& Gaeth 1990; Lichtenstein et al., 1993).

The role of price cue in consumer buying process is a debate between positive impact and negative role. Under the assumption of information perfection, price is an indicator of purchase cost. However, in reality, consumers usually do not have complete information about products and confront to the quality uncertainty of products, price could be a stimuli for product quality (Monroe, 1973). The role of price in consumer purchasing also depends on how consumers utilize this cue to make their decision. The negative role could be a result of a concern about the consistency between price paid and quality received; the relevancy of price in comparison to other reference prices; the positive respond to the seller actions. The positive role could be observed in a group of price seeking consumers, who prefer high price product in product category or prestige sensitive consumers, who consider price as an indicator of sellers' reputation.

In this study, due to the particular purchasing situation (dinning out at food service outlets) and the characteristic of the product (the imported beef brands), we hypothesized that:

H2a: When dining out at food service outlets in the Vietnamese market, consumers with stronger favor for newly imported beef brands would need for more information about country of origin

H2b: When dining out at food service outlets in the Vietnamese market, consumers with stronger favor for newly imported beef brands would reduce the price consciousness of beef.

\subsection{Usage Experience and Innovativeness toward New Beef Brands}

Nelson $(1970,1974)$ indicated that the value of information in consumer utility depended on the type of a product. For the experience goods, usage experience of individual is more valuable than external information sources since the attributes of this product is evaluated merely after purchasing. Regarding the consumer knowledge, usage experience could be one item in consumer knowledge construction. Usage experience could affect product familiarity, information integration process and consumers' decision-making confidence (Brucks, 1985; Ha \& Perks, 2005; Laroche et al., 1996; Park \& Lessig, 1981; Urbany et al., 1989). Hence, how consumers evaluate new beef brands might depend on their cumulative beef-eating experience, especially one's personal ability to differentiate between the origin of a variety of beef using intrinsic cues (Bredahl, 2004; Verbeke \& Ward, 2006). We hypothesized that eating experience could positively impact on the consumer innovativeness toward new beef brands at food service outlets. We also differentiated the affect of general eating experience and professional eating experience on adoptive behavior process following the hierarchy cognition of innovation (Rorger, 2003). The general experience reflected the familiarity of consumers with product category and purchasing situation while the professional experience indicated the personalized knowledge of consumers about specific characteristics of the particular products. The professional experience also presented the high involvement of consumers in the buying process. We considered the professional experience is higher than the general experience in hierarchy cognitive process.

H3a: The eating experience could positively impact on consumer innovativeness toward new beef brands when dinning out at food service outlets in the Vietnamese market

H3b: The general experience could lead to the professional experience of beef at food service outletswhen dinning out at food service outlets in the Vietnamese market

H3c: The professional experience is stronger than the general experience in explaining consumer innovativeness toward beef when dinning out at food service outlets in the Vietnamese market

\subsection{The Moderating Role of Usage Experience on Consumer Innovativeness}

Regarding the uncertainty of beef quality at foodservice outlets, we argued at the 3.2 that the need for information about country of origin, and price concerns were derived from the need for new beef. However, the requirements for external information can be moderated by subjective knowledge and product familiarity (Campbell \& Keller, 2003; Johnson \& Russo, 1984; Laroche et al., 1996). Hence, the need for information about $\mathrm{COO}$ and price consciousness were jointly considered with the general experience and the professional experience of beef when dinning out at food service outlets.

Since consumer adoption was a multi-stage process, we hypothesized that increasing information about country 
of origin could accelerate the innovativeness toward new beef brands through enhancing the eating experiences of new beef brands. Moreover, when the eating experiences were motivated, these could reduce the concerns about the price at the first time introduction.

H4a: Increasing information about country of origin could accelerate the innovativeness toward new beef brands at food service outlets through enhancing eating experiences of new beef brands

H4b: Increasing information about country of origin could reduce the price consciousness of new beef brands at food service outlets in the Vietnamese marketthrough enhancing eating experiences of new beef brands.

The conceptual framework of our study is shown in Figure 1.

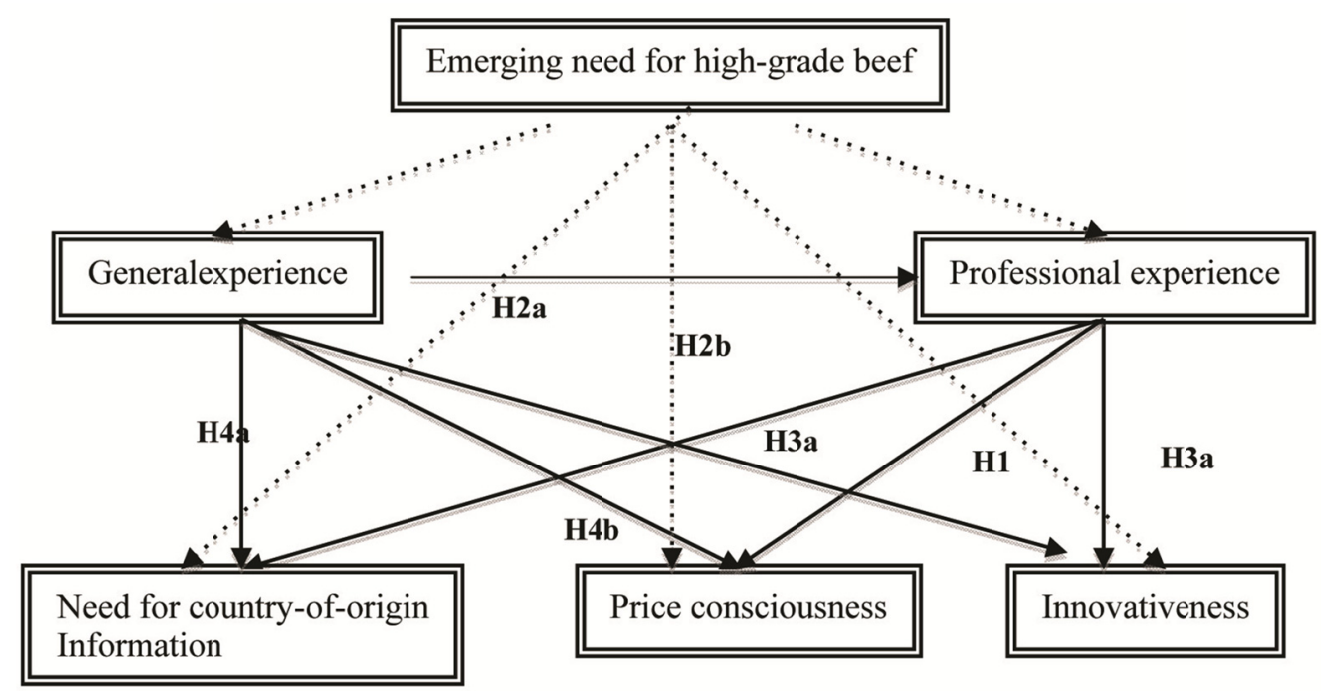

Figure 1. The conceptual framework of the study

\section{Methodology}

\subsection{The Beef Market in Vietnam and the Variable Measurement}

We selected Ho Chi Minh City (hereafter HCMC) as the research area to conduct the consumer survey because of three reasons. First, Ho Chi Minh City is the most dynamic metropolitan with the highest GDP per capita in Vietnam. Second, imported beef dominated the HCMC beef market due to the shortage of domestic supply. Last, there exist an emerging need for high-grade beef products of consumers from upper middle-income class as the result of Westernized eating preference and cultural integration.

The main beef exporters in Ho Chi Minh City market are Australian beef exporters and American beef exporters. Australian beef cuts were initially imported into HCMC market in 2002. From 2012, the local importers have imported Australian whole beef cattle and slaughtered these cattle domestically. Hence, Australian beef occupied the fresh beef market in HCMC. In 2008, Australian Wagyu beef was imported into HCMC market at the first time and opened the avenues for premium beef brands at this market. From June 2014, Japanese Wagyu beef was imported into HCMC and became the last entrant beef brand in this market. Even though no official data of the Vietnam Customs indicated the importing of Kobe beef, this beef brand has been famous at HCMC and was transported by hand carrier to the HCMC market. However, Kobe beef has previous scandal related to the counterfeit product at food service outlets due to the opportunistic behavior of restaurants. After this negative publicity, consumers have been cautious when buying high-grade beef at food service facilities.

Most of the consumers in the HCMC market differentiated beef by country of origin, for example, Australian beef, American beef, and Japanese beef. For Kobe beef, consumers considered it under the brand name "Kobe beef" due to its strong impacts onconsumer's consciousness even though this beef is one kind of Japanese Wagyu beef. There is no official requirement of the Vietnamese government for public information about beef products at the retail market as well as the traceability of imported beef products. Consumers have to deal with the riskiness from information imperfection by their ability.

Hence, in this study, we constructed a multivariate measurement for the need for information about country of 
origin as well as price concerns when dinning out at food service outlets. To measure each item in the need for information about country of origin ( $\mathrm{NeCOO}$ ), price consciousness (PriceConscious), each respondent gave an individual opinion about each statement through using five-point Likert scale with 1 for completely do not agree to 5 for completely agree. Instead of asking the direct evaluation for the importance of each item, we changed the asking method to match with the Vietnamese consumers.

Regarding Innovativeness, each respondent had to confirm three statements about choosing a new beef brand at restaurants, with 1 for completely incorrect to 5 for completely correct. Since the main purpose of consuming high -grade beef in the restaurants is enjoyment and exploration, innovativeness could interchange for varietyseeking behavior or exploratory behavior.

The newly imported beef brands at the HCMC market consist of Australian Wagyu beef, Japanese Wagyu beef, and Kobe beef; thus, the emerging need for high-grade beef was measured through consumer preference for three newly imported beef brands.

To measure the eating experience, we used eating frequency in one month as a predictor for the general experience and constructed 3 questions for the professional experience. We focused on the recognizable ability through 3 intrinsic cues: tenderness, flavor, and marbling. A detailed explanation of variable measurement is provided in Table 1 below.

Table 1. Explanation of variable measurement

\begin{tabular}{|c|c|}
\hline \multicolumn{2}{|c|}{ Endogenous Latent Variables ( $5=$ totally agree; $1=$ totally disagree) } \\
\hline \multirow[t]{6}{*}{$\mathrm{NedCOO}$} & The need for information about country of origin at food service outlets in Vietnam \\
\hline & $\mathrm{C} 1=$ Restaurants must intend to provide customers with country-of-origin information. \\
\hline & $\mathrm{C} 2=$ Restaurants must provide customers with country-of-origin information. \\
\hline & $\mathrm{C} 3$ = Restaurants must have legal country-of-origin certificates for beef. \\
\hline & $\mathrm{C} 4=$ Staff in restaurants must have sufficient knowledge about beef dishes' country of origin. \\
\hline & $\mathrm{C} 5=$ Restaurants must provide customers with beef that has country of origin as informed by restaurants. \\
\hline \multirow[t]{4}{*}{ Price Conscious } & Consumer consciousness of beef price at food service outlets in Vietnam \\
\hline & $\mathrm{P} 1=$ The price of beef must be reasonable at the retail market. \\
\hline & $\mathrm{P} 2=$ The price of beef must be acceptable at food service outlets. \\
\hline & $\mathrm{P} 3=$ The price of beef must be stable for a given period. \\
\hline \multirow[t]{4}{*}{ ProExp } & Personal ability to evaluate beef. \\
\hline & $\mathrm{A} 1=\mathrm{I}$ can recognize the kind of beef through its flavor. \\
\hline & $\mathrm{A} 2=\mathrm{I}$ can recognize the kind of beef through its tenderness. \\
\hline & A3 $=$ I can recognize the kind beef through its marbling content. \\
\hline Familiarity & Frequency of eating beef at restaurants (times/month) \\
\hline \multirow[t]{4}{*}{ Inn } & Innovativeness towards new beef brands ( $5=$ completely correct; $1=$ completely incorrect) \\
\hline & $\mathrm{I} 1$ = I tend to diversify my beef choices when dining out at restaurants. \\
\hline & $\mathrm{I} 2=\mathrm{I}$ tend to choose beef that is different from beef cooked home when dining out at restaurants. \\
\hline & $\mathrm{I} 3=\mathrm{I}$ tend to try new kinds of beef at a market when dining out at restaurants. \\
\hline \multicolumn{2}{|c|}{ Exogenous Latent Variables } \\
\hline \multirow[t]{4}{*}{ Emer Need } & Emerging need for high-grade beef at food service ( $5=$ Greatly prefer; $1=$ Do not prefer) \\
\hline & $\mathrm{WAU}=$ Preference for Australian Wagyu beef at restaurants \\
\hline & $\mathrm{JPW}=$ Preference for Japanese Wagyu beef at restaurants \\
\hline & $\mathrm{KOBE}=$ Preference for Kobe beef at restaurants \\
\hline
\end{tabular}




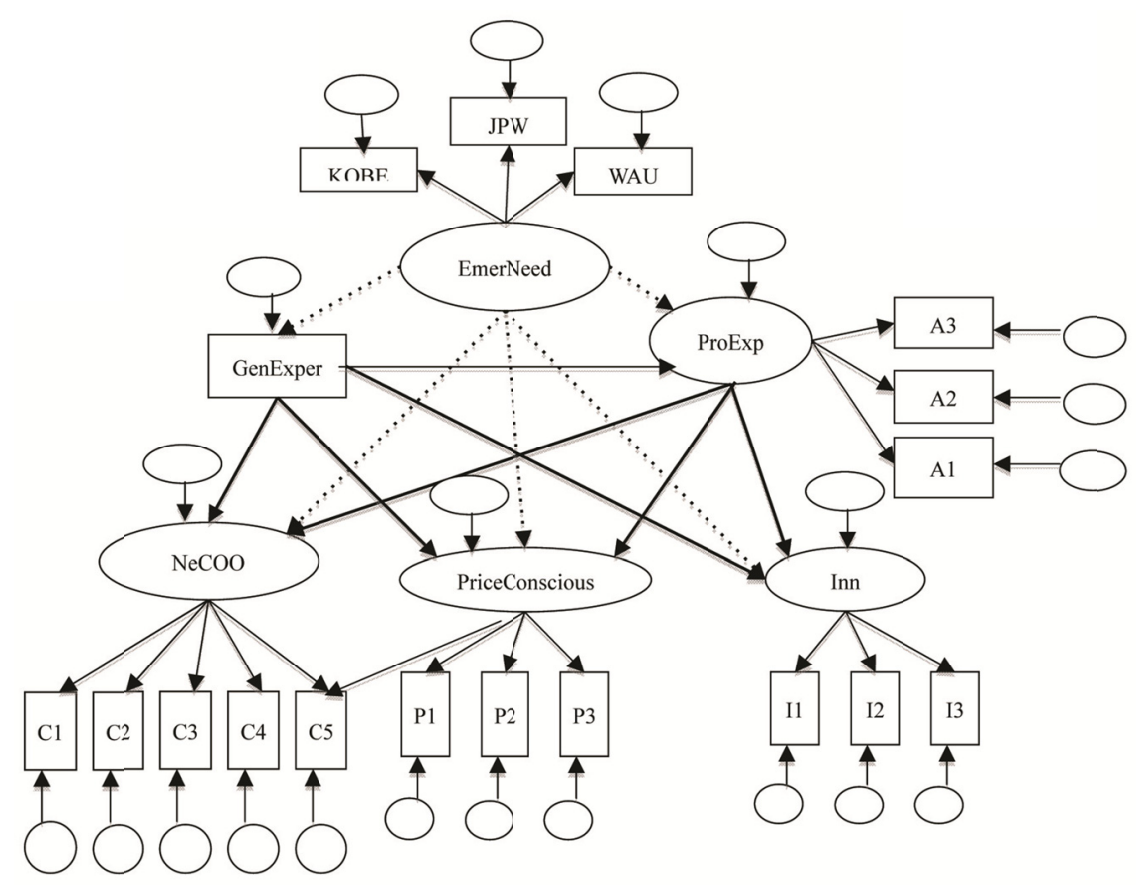

Figure 2. The structural equation model of the study

\subsection{Data Collection and the Sample Description}

We collected the data for this study through the random direct interviews with 480 customers at beef restaurants in the urban area of Ho Chi Minh City, Vietnam from August 15th to September 25th, 2015. Since our study concentrated on the newly imported beef brands at food service outlets, we required that respondents had basic knowledge of eating beef in restaurants. We used three screening questions to assure that respondents were relevant to our research purposes. A beef restaurant in our study was defined as an intermediated-grade restaurant with beef as main courses on its menu.

Table 2. The socio-economic characteristics of the sample

\begin{tabular}{lll}
\hline Characteristics & Description & Percentage \\
\cline { 2 - 3 } & Value & $100 \%$ \\
\hline Age & $\mathrm{N}=480$ & $13.13 \%$ \\
$18 \sim 25$ years old & 63 & $47.50 \%$ \\
$25 \sim 35$ years old & 228 & $39.37 \%$ \\
\hline Over 35 years old & 189 & $100 \%$ \\
\hline Education & $\mathrm{N}=480$ & $16.67 \%$ \\
High-school degree & 80 & $68.96 \%$ \\
Bachelor degree & 331 & $14.37 \%$ \\
Master/Doctor degree & 69 & $100 \%$ \\
\hline Average food expenditure per month in a household & $\mathrm{N}=480$ & $21.88 \%$ \\
\hline $8 \sim 14$ million VND & 105 & $40 \%$ \\
$14 \sim 20$ million VND & 192 & $20.41 \%$ \\
$20 \sim 26$ million VND & 98 & $17.71 \%$ \\
26 million VND & 85 & \\
\hline
\end{tabular}

It could be seen from the table 2 that our sample reflected the current characteristics of urban customers at food service in Vietnam. The respondents with the age from 25 35 years old accounted for the largest share, at about $48 \%$ of the sample. Most of the respondents obtained the college or university degree and had food expenditure per month higher than the average spending in HCMC. The characteristics of our sample seem to be relevant to the purpose of the study on consumer innovativeness since high education, upper middle income, and young age constitute the psychological portrait of innovators in literature. 


\section{Results}

\subsection{Hypothesis Testing}

Table 3. Descriptive summary of variables

\begin{tabular}{|c|c|c|c|}
\hline Variable & Mean & Std. Dev. & Factor loading \\
\hline \multicolumn{4}{|c|}{ PriceConscious (Cronbach's alpha $=0.644$ ) } \\
\hline $\mathrm{P} 1$ & 3.906 & 0.972 & 0.59 \\
\hline $\mathrm{P} 2$ & 3.517 & 1.024 & 0.60 \\
\hline $\mathrm{P} 3$ & 3.460 & 1.006 & 0.51 \\
\hline \multicolumn{4}{|c|}{ NeedCOO(Cronbach's alpha=0.741) } \\
\hline $\mathrm{C} 1$ & 4.415 & 0.740 & 0.62 \\
\hline $\mathrm{C} 2$ & 4.385 & 0.710 & 0.64 \\
\hline $\mathrm{C} 3$ & 4.233 & 0.832 & 0.55 \\
\hline $\mathrm{C} 4$ & 4.150 & 0.788 & 0.46 \\
\hline $\mathrm{C} 5$ & 4.548 & 0.679 & 0.66 \\
\hline \multicolumn{4}{|c|}{ Inn (Cronbach's alpha $=0.607)$} \\
\hline I1 & 3.512 & 1.111 & 0.45 \\
\hline $\mathrm{I} 2$ & 3.800 & 1.020 & 0.52 \\
\hline $\mathrm{I} 3$ & 3.252 & 1.174 & 0.51 \\
\hline \multicolumn{4}{|c|}{ ProExp (Cronbach’s alpha=0.604) } \\
\hline A1 & 3.052 & 1.073 & 0.58 \\
\hline A2 & 3.410 & 1.038 & 0.45 \\
\hline $\mathrm{A} 3$ & 3.008 & 1.040 & 0.54 \\
\hline \multicolumn{4}{|c|}{ EmerNeed (Cronbach's alpha $=0.592$ ) } \\
\hline WAU1 & 2.988 & 0.791 & 0.59 \\
\hline KOBE1 & 3.025 & 1.139 & 0.53 \\
\hline JP1 & 2.785 & 0.870 & 0.44 \\
\hline Frequency & 2.81 & 1.08 & \\
\hline
\end{tabular}

Table 3 reported the descriptive statistics for each item of exogenous latent variables and endogenous latent variables. The internal consistency and reliability of instruments were measured by Cronbach's coefficient alpha (Cronbach, 1951) and exploratory factor analysis. Following previous studies on the lower bound of acceptable alpha value in psychology (Gliem \& Gliem, 2003; Sijtsma, 2009; Tuckman \& Harper, 2012), we take $\alpha=0.6$ as a lower threshold of measurement reliability. In general, all instruments indicated alpha values that exceed the acceptable criterion of 0.6 , except for behavior measurement with $\alpha=0.592$. Regarding to factor analysis, we used 0.4 as the threshold to retain the relevant item in a factor (Ford, MacCallum, \& Tait, 1986).

Table 4. Values of fit statistics

\begin{tabular}{lll}
\hline Index & Values & \\
\hline & OIM estimate & Satorra-Bentler estimation \\
$\chi^{2}(\mathrm{df})$ & $230.96(123)$ & $200.69(123)$ \\
$\mathrm{P}>\chi^{2}$ & 0.000 & 0.000 \\
$\chi^{2}(\mathrm{df}) / \mathrm{df}$ & 1.877 & 1.682 \\
RMSEA $(90 \% \mathrm{CI})$ & $0.043(0.034 ; 0.051)$ & 0.036 \\
$\mathrm{P}$-close fit $\mathrm{H}_{0}$ & 0.920 & \\
CFI & 0.915 & 0.930 \\
TLI & 0.895 & 0.913 \\
SRMR & 0.047 & \\
CD & 0.699 & \\
\hline
\end{tabular}

Note. CI. Interval confidence. All results were calculated by STATA.

OIM. Observed Information Matrix.

Table 4 presented values for fit statistics of the structural equation model in our study. The model's chi-square was statistically significant at $p$-value $<0.01$. Thus, the exact-fit hypothesis was rejected at $1 \%$ when considering the model's test statistic. In other words, the covariance matrix implied by our model was not close enough to the sample covariance matrix because of other reasons rather than sample error (Kline, 2011). Due to the sensitivity 
of the observed value of $\chi_{M}^{2}$ (df), with multivariate non-normality and sample size (Bentler \& Yuan, 1999; Hayduk et al., 2007; Yuan, 2005), we considered approximate fit indices to evaluate goodness-of-fit for the specified model. The value of RMSEA at $0.043<0.05$ indicated relatively adequate fitness (Brown \& Stayman, 1992; MacCallum, Browne, \& Sugawara, 1996). The relative fit of the model is about a $91.50 \%$ improvement over that of an independent model $(\mathrm{CFI}=0.915)$. SRMR was at $0.047<0.05$ and sufficient for fitting the model (Hu \& Bentler, 1998, 1999). Since we attempted to construct a comprehensive model for testing the impact information at an individual level, this model could be relevant to some extent with relaxed statistical indicators for goodness-of-fit.

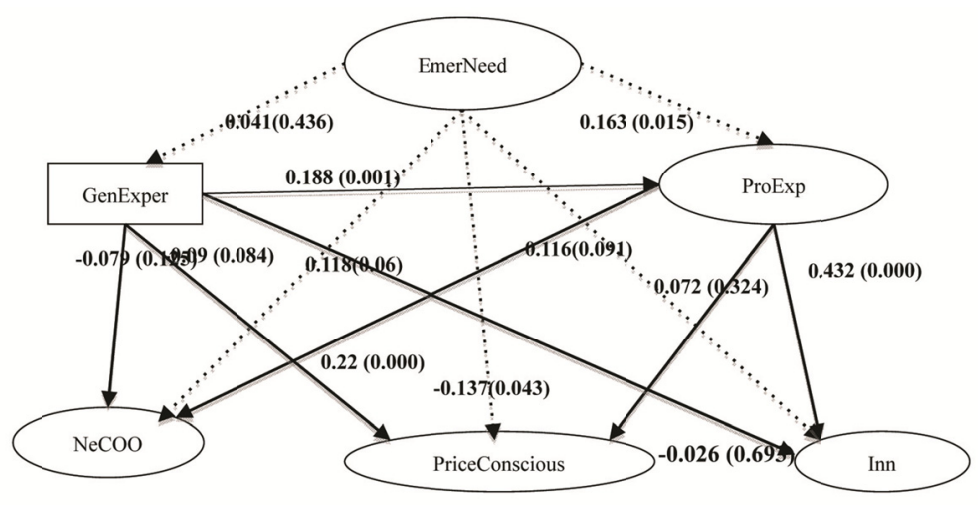

Figure 3. Maximum likelihood parameter estimates for the paths in the study

Note. Standardized coefficient estimates are reported with the p-value in the parentheses.

Table 5. The summary of the hypothesis testing

\begin{tabular}{|c|c|c|c|}
\hline \multirow[t]{2}{*}{ Hypothesis } & \multirow[t]{2}{*}{ Path/Covariance } & \multicolumn{2}{|l|}{ Coefficient } \\
\hline & & Ust. & St. \\
\hline \multirow{3}{*}{ H1 } & EmerNeed->Inn & 2.676 & 0.189 \\
\hline & Direct & 1.646 & 0.116 \\
\hline & Indirect & 1.030 & 0.073 \\
\hline \multirow[t]{3}{*}{$\mathrm{H} 2 \mathrm{a}$} & EmerNeed->NeCOO & 1.618 & 0.153 \\
\hline & Direct & 1.253 & $0.118^{*}$ \\
\hline & Indirect & 0.036 & 0.035 \\
\hline \multirow[t]{3}{*}{$\mathrm{H} 2 \mathrm{~b}$} & EmerNeed->PriceConsious & -0.415 & -0.129 \\
\hline & Direct & -0.442 & $-0.137 * *$ \\
\hline & Indirect & 0.027 & 0.008 \\
\hline \multirow[t]{3}{*}{ H3a (1) } & ProExp->Inn & $0.414 * * *$ & $0.432 * * *$ \\
\hline & Direct & $0.414 * * *$ & $0.432 * * *$ \\
\hline & Indirect & & \\
\hline \multirow[t]{3}{*}{ H3a (2) } & GerExp->Inn & 0.032 & 0.055 \\
\hline & Direct & -0.016 & -0.026 \\
\hline & Indirect & $0.047 * * *$ & 0.081 \\
\hline \multirow[t]{3}{*}{$\mathrm{H} 3 \mathrm{~b}$} & GeExp->ProExp & $0.115^{* * *}$ & $0.188 * * *$ \\
\hline & Direct & $0.115^{* * * *}$ & $0.188 * * *$ \\
\hline & Indirect & & \\
\hline \multirow[t]{3}{*}{$\mathrm{H} 4 \mathrm{a}(1)$} & ProExp->NeCOO & $0.158 * * *$ & $0.220 * * *$ \\
\hline & Direct & $0.158^{* * *}$ & $0.220 * * *$ \\
\hline & Indirect & & \\
\hline \multirow[t]{3}{*}{$\mathrm{H} 4 \mathrm{a}(2)$} & GerExp->NeCOO & -0.017 & -0.038 \\
\hline & Direct & -0.035 & -0.079 \\
\hline & Indirect & $0.018^{* * *}$ & 0.041 \\
\hline \multirow[t]{3}{*}{$\mathrm{H} 4 \mathrm{~b}(1)$} & ProExp-> PriceConsious & 0.016 & 0.072 \\
\hline & Direct & 0.016 & 0.072 \\
\hline & Indirect & & \\
\hline \multirow[t]{3}{*}{$\mathrm{H} 4 \mathrm{~b}(2)$} & GerExp-> PriceConsious & -0.017 & \\
\hline & Direct & -0.123 & -0.093 \\
\hline & Indirect & $0.002 * * *$ & 0.014 \\
\hline
\end{tabular}

Note. ${ }^{* * *}$-value $<0.01 ; * *$ p-value $<0.05 ;{ }^{*}$ p-value $<0.1 ;$ Utd. Unstandardized estimate; Std. Standardized estimate. 
Table 6. Decomposition for the Impacts of EmerNeed, ProExp, and GeExp on the Endogenous Variables

\begin{tabular}{lllllll}
\hline & EmerNeed & & ProExp & & GeExp \\
\hline & Unst. & St. & Unst. & St. & Unst. & St. \\
Inn & & & & & \\
Indirect Effect & & & & & & 0.031 \\
Inn1 & 2.676 & 0.108 & $0.414^{* * *}$ & 0.247 & 0.032 & 0.033 \\
Inn2 & 2.572 & 0.113 & $0.398^{* * *}$ & 0.258 & 0.031 & 0.032 \\
Inn3 & 2.918 & 0.111 & $0.451^{* * *}$ & 0.254 & 0.035 & \\
\hline NeCOO & & & & & & -0.024 \\
Indirect Effect & & & & & & -0.025 \\
C1 & 1.680 & 0.098 & $0.158^{* * *}$ & 0.141 & -0.017 & -0.021 \\
C2 & 1.620 & 0.102 & $0.158^{* * *}$ & 0.147 & -0.016 & -0.018 \\
C3 & 1.598 & 0.086 & $0.156^{* * *}$ & 0.124 & -0.016 & -0.041 \\
C4 & 1.285 & 0.073 & $0.126^{* * *}$ & 0.106 & -0.013 & \\
C5 & 1.079 & 0.071 & $0.161^{* * *}$ & 0.159 & -0.026 & -0.053 \\
\hline PriceConscious & & & & & & -0.052 \\
Indirect Effect & & & & & & -0.040 \\
P1 & -1.874 & -0.086 & 0.071 & 0.048 & -0.048 & -0.050 \\
P2 & -1.950 & -0.085 & 0.074 & 0.047 & -0.038 & \\
P3 & -1.483 & -0.066 & 0.056 & 0.037 & & \\
\hline
\end{tabular}

Note. ${ }^{* *}$ p-value $<0.01 ; * *$ p-value $<0.05 ;{ }^{*}$-value $<0.1 ;$ Unst. Unstandardized estimate; St. Standardized estimate.

Table 5 presented the results of the hypotheses in the figure 1 using the SEM shown in the figure 2. Regarding the impact of the emerging need for high-grade beef at food service outlets on the consumer innovativeness toward beef, H1 was not kept when the standardized coefficient of the path from EmerNeed to Inn is 0.116 at $\mathrm{p}$-value $=0.101$.

$\mathrm{H} 2 \mathrm{a}$ was kept at $\mathrm{p}$-value $<0.1$ with the standardized coefficient of the direct path from EmerNeed to $\mathrm{NeCOO}$ was 0.118 at p-value $<0.01$. Customers with stronger favor for new kinds of beef in the market require more information about country of origin of beef. However, no significant effect could be seen for the indirect impact of EmerNeed on each observed endogenous variable in the latent instrument $\mathrm{NeCOO}$. The emerging need for high-grade beef indicated significant impact on PriceConscious variable with the standardized coefficient of the direct path is -0.137 at $p$-value $<0.05$. Customers with high preference for high-grade beef brands tended to reduce the role of price in their purchases when dinning out at the beef restaurants. Similar to the results of $\mathrm{NeCOO}$, no significant effect could be seen for indirect impact of EmerNeed on PriceConscious as well as three observed endogenous variables of the instrument PriceConscious.

About the variables related to the eating experience, the professional experience in beef recognition was a result of the general experience in dinning out at beef restaurant. Alternatively, H3b was supported when the standardized coefficient of the direct path from the general experience to the professional experience was 0.188 at $\mathrm{p}$-value $<0.01$. This result confirmed that professional experience, which expressed the personal ability in using sensory cues to differentiate beef brands at food service outlets, was at the higher position in consumer's cognitive hierarchy than the general similarity.

$\mathrm{H} 3 \mathrm{a}$ was kept for the direct effect from the professional experience to innovativeness at $\mathrm{p}$-value $<0.01$ while the significant indirect effect was observed for the general experience. Among three observed endogenous variables in Inn variable, the largest indirect impact of the professional experience was seen for I3, which indicated the intention to explore the new beef brand at the market. This finding could be relevant when considering the purchasing situation, the studied item, and the demographic characteristics of the sample. Since eating beef, especially high-grade beef at restaurants is the result of Westernized eating habit and life style of young consumers with upper middle income in urban areas, sensory experience is a motivation of variety seeking at food service.

H4a was kept with the standardized direct effect from PerExp to NeCOO was at 0.220 at p-value $<0.01$ and the unstandardized indirect effect from GeExp to $\mathrm{NeCOO}$ was 0.018 at p-value $<0.01$. Eating experience becomes the moderator between the need for country of origin information and the innovativeness toward the new beef at the restaurants. Since the adoptive behavior is a multi-stage process, increasing information about country of origin can enhance similarity and personal ability in evaluating beef, consequently lead to the adoptive behavior for the new beef brand. The forth column of the table 4 indicated the indirect impact of the professional experience on the requirements of country of origin at beef restaurants. It could be seen that the most 
considerable requirement was a question of whether or not the beef restaurants would provide customers with the beef with country of origin as informed. Alternatively, one of the major uncertainties of consuming beef at food service outlets for customers is about opportunistic behavior of restaurants. This result reflected the actual problem of beef purchasing at the beef restaurants in the Vietnamese market since there is no official program as well as the government regulation to protect consumers' rights.

$\mathrm{H} 4 \mathrm{~b}$ was not supported since there was no significant effect could be seen in the direct path from eating experience to the consciousness of price of beef at the beef restaurant, except for a minor indirect impact of general experience at 0.002 with $\mathrm{p}$-value $<0.01$. As explained in the $\mathrm{H} 2 \mathrm{a}$, consumers seemed not to paid high attention to the price of beef when dinning out at the beef restaurants.

\section{Discussion}

The results from the SEM indicated the importance of information about country of origin and price in private adoption for the new beef brands at food service outlets in Vietnam. The positive impact of emerging need for high-grade beef at food service on the need for information about country of origin expressed the uncertainty of beef consuming at the restaurants in the Vietnamese market. It also expressed the high searching cost of consumers before purchasing beef at restaurants due to the unavailability of information about products. This finding was one evidence for the role of COO in signaling beef quality to consumers (Cicia, Giudice, \& Scarpa, 2002; Gao \& Schroeder, 2009). Moreover, price of beef at the food service outlets served as a quality cue of the beef when customers with high preference for new beef products reduced their price concerns in their buying process. These findings suggested that beef marketing agencies at food service should focus on establishing consumer belief through providing transparent information about beef brands as well as ensured quality beef products instead of inferior products with low price.

The large impact of professional experience on the innovativeness for beef showed that the personal experience was the most reliable source when evaluating beef at food service outlets. This finding was consistent with the conclusion of Grunert (1997). Personal cumulative experience in using sensory cueswas the crucial determinant of consumer innovativeness. This finding pointed out the importance of the sensory adoption process in promoting experience goods as beef. Moreover, the stronger impact of professional experience on innovativeness than general experience indicated the role of product trial and exploration in promotional program for new beef brands at food service. Since customers at dining out are variety-seekers, it is principal for beef marketers to individualized beef eating experience through trial offers.

The positive impact of professional experience on the need for country-of-origin information highlighted the mechanism of enhancing consumer innovativeness for beef at restaurants in Vietnam through marketing communication. At first, due to the high uncertainties of new beef brands, consumers with professional experience require more information about country of origin. The further information plays two roles in this group. First, it serves as the diagnostic of the bias in prior knowledge of consumers. Second, it can inspire the learning about new brand of expertise consumers. Hence, if marketing agencies could increase the awareness about new beef brands through providing more information about country of origin, they could accelerate the innovativeness toward such new beef brands through the positive moderator named personal experience.

There was no significant impact of purchasing familiarity on consumers' innovative attitudes, the need for country of origin information, and price concerns except for very minor indirect effect on NeCOO. Frequency of eating out was insignificant in explaining customers' attitudes and behaviors, due to individualization in beef purchasing at food service outlets. The specific characteristics of a purchasing situation call for stronger factors, such as external cues or personalization of an eating experience, rather than the frequency of dining out.

\section{Conclusion}

This study investigated the impacts of the need for information about country of origin and price consciousness on consumer innovativeness toward imported beef brands at food service outlets in Vietnam. The SEM's findings indicated that the country of origin and price were the major external cues for in beef quality evaluation at food service outlets in Vietnam. The need for further information about country of origin and price consciousness were the results of the emerging need for new beef brands and the uncertainties from the new beef brands at the restaurants. Price served as the quality cue for beef at the beef restaurants, while consumers used country-of-origin information as a source of exploratory behavior and risk reduction in purchasing beef at restaurants. Consumers tended to consider the consistency between information about country of origin and the actual action of restaurants when trying a new beef brand.

The individual's ability to recognize brands of beef considerably influenced consumer innovativeness and the 
need for information about new imported beef brands. Via three intrinsic cues, including flavor, tenderness, and marbling content, personal ability indicated the importance of an individualized eating experiences in consuming beef at food service outlets. Customers at restaurants tended to use both information sources, giving more weight to their personal eating experience. The insignificant impact of dining out frequency also confirmed the role of personal exploration and experience when eating beef at food service outlets.

Our study focuses on specific questions, so a need exists for future investigations, as well as for a reexamination of our results. The first shortcoming of our study comes from the highly restricted requirements imposed on respondents. Since our study specialized in the niche market for imported beef brands at food service outlets, it seems acceptable to use this framework for potential adopters. However, since screening procedure narrowed the population of our study our findings should be interpreted seriously for other purchasing situations.

Another problem of our study is the measurement of variables. We used 0.6 as the lower bound for the reality of scale of demand for information at food service outlets. Even though this value could be acceptable for an exploratory study on attitude, it seems to be poorly related to reality to some extent. Hence, the scale measurement should be revised and reinvestigated in future studies.

Due to the specific characteristics of a purchasing situation in the Vietnamese market, other explanatory variables could be used for innovative attitudes besides the need for information about country of origin, price consciousness, and personal experience. One possible example is the reputation of restaurants, or the difference in a restaurant's concept of cuisine. Hence, our model, as well as its findings, should be considered in accordance with contextual factors.

\section{References}

Arts, J. W. C., Frambach, R. T., \& Bijmolt, T. H. A. (2011). Generalizations on consumer innovation adoption: A meta-analysis on drivers of intention and behavior. International Journal of Research in Marketing, 28(2), 134-144. https://doi.org/10.1016/j.jiresmar.2010.11.002

Bentler, P., \& Yuan, K. H. (1999). Structural Equation Modeling with Small Samples: Test Statistics. Multivariate Behavioral Research, 34(2), 181-197. https://doi.org/10.1207/S15327906Mb340203

Bernués, A., Olaizola, A., \& Corcoran, K. (2003). Extrinsic attributes of red meat as indicators of quality in Europe: An application for market segmentation. Food Quality and Preference. https://doi.org/10.1016/S0950-3293(02)00085-X

Bredahl, L. (2004). Cue utilisation and quality perception with regard to branded beef. Food Quality and Preference, 15(1), 65-75. https://doi.org/10.1016/S0950-3293(03)00024-7

Brown, S. P., \& Stayman, D. M. (1992). Antecedents and Consequences of Attitude Toward the Ad: A Meta-Analysis. Journal of Consumer Research, 19(1), 34. https://doi.org/10.1086/209284

Brucks, M. (1985). The on Effects of Product Search Class Knowledge Information Behavior*. Journal of Consumer Research, 12(1), 1-16. https://doi.org/10.1086/209031

Campbell, M. C., \& Keller, K. L. (2003). Brand Familiarity and Advertising Repetition Effects. Journal of Consumer Research, 30(2), 292-304. https://doi.org/10.1086/376800

Cicia, G., Giudice, T. D., \& Scarpa, R. (2002). Consumers' perception of quality in organic food: A random utility model under preference heterogeneity and choice correlation from rank-orderings. British Food Journal, 104(3/4/5), 200-213. https://doi.org/10.1108/00070700210425660

Dobre, C., Dragomir, A., \& Preda, G. (2009). Consumer innovativeness: a marketing approach. Management \& Marketing, $\quad 4(2), \quad 19-34 . \quad$ Retrieved from http://www.managementmarketing.ro/pdf/articole/133.pdf\%5Cnhttp://econpapers.repec.org/article/ephjourn 1/v_3a4_3ay_3a2009_3ai_3a2_3an_3a2.htm

Ford, J. K., MacCallum, R. C., \& Tait, M. (1986). The Application of Exploratory Factor Analysis in Applied Psychology: A Critical Review and Analysis. Personnel Psychology. https://doi.org/10.1111/j.1744-6570.1986.tb00583.x

Fu, W., Gandhi, V. P., Cao, L., Liu, H., \& Zhou, Z. (2012). Rising Consumption of Animal Products in China and India: National and Global Implications. China and World Economy, 20(3), 88-106. https://doi.org/10.1111/j.1749-124X.2012.01289.x

Gandhi, V. P., \& Zhou, Z. (2010). Rising Demand for Livestock Products in India. Australasian Agribusiness Review, 18, 103-135. 
Gao, Z., \& Schroeder, T. C. (2009). Effects of label information on consumer willingness-to-pay for food attributes. American Journal of Agricultural Economics, 91(3), 795-809. https://doi.org/10.1111/j.1467-8276.2009.01259.x

Gatignon, H., \& Robertson, T. S. (1985). A Propositional Inventory for New Diffusion Research. Journal of Consumer Research, 11(4), 849-867. https://doi.org/10.1086/209021

Gliem, J. A., \& Gliem, R. R. (2003). Calculating, interpreting, and reporting Cronbach's alpha reliability coefficient for Likert-type scales. Midwest Research to Practice Conference in Adult, Continuing, and Community Education, (1992), 82-88. https://doi.org/10.1109/PROC.1975.9792

Grunert, K. G. (1997). What's in a steak? A cross-cultural study on the quality perception of beef. Food Quality and Preference, 8(3), 157-174. https://doi.org/10.1016/S0950-3293(96)00038-9

Grunert, K. G., Bredahl, L., \& Brunsø, K. (2004). Consumer perception of meat quality and implications for product development in the meat sector-A review. Meat Science, 66(2), 259-272. https://doi.org/10.1016/S0309-1740(03)00130-X

Ha, H. Y., \& Perks, H. (2005). Effects of consumer perceptions of brand experience on the web: Brand familiarity, satisfaction and brand trust. Journal of Consumer Behaviour, 4(6), 438-452. https://doi.org/10.1002/cb.29

Hayduk, L., Cummings, G., Boadu, K., Pazderka-Robinson, H., \& Boulianne, S. (2007). Testing! testing! one, two, three-Testing the theory in structural equation models! Personality and Individual Differences, 42(5), 841-850. https://doi.org/10.1016/j.paid.2006.10.001

Hirschman, E. C. (1980). Innovativeness, novelty seeking, and consumer creativity. Journal of Consumer Research, 7(December), 283-295. https://doi.org/10.1086/208816

Hu, L. T., \& Bentler, P. M. (1998). Fit indices in covariance structure modeling: Sensitivity to underparameterized model misspecification. Psychological Methods, 3(4), 424-453. https://doi.org/10.1037//1082-989x.3.4.424

Hu, L., \& Bentler, P. M. (1999). Cutoff criteria for fit indices in covariance structure analysis: Conventional criteria versus new alternatives. Structural Equation Modeling, 6, 1-55. https://doi.org/10.1080/10705519909540118

Johnson, E. J., \& Russo, J. E. (1984). Product Familiarity and Learning New Information. Journal of Consumer Research, 11(1), 542. https://doi.org/10.1086/208990

Kim, R. (2008). Japanese consumers' use of extrinsic and intrinsic cues to mitigate risky food choices. International Journal of Consumer Studies, 32(1), 49-58. https://doi.org/10.1111/j.1470-6431.2007.00636.x

Labay, D. G., \& Kinnear, T. C. (1981). Exploring the Consumer Decision Process in the Adoption of Solar Energy Systems. Journal of Consumer Research, 8(3), 271-278. https://doi.org/10.1086/208865

Laroche, M., Kim, C., \& Zhou, L. (1996). Brand familiarity and confidence as determinants of purchase intention: An empirical test in a multiple brand context. Journal of Business Research, 37(2), 115-120. https://doi.org/10.1016/0148-2963(96)00056-2

MacCallum, R., Browne, M. W., \& Sugawara, H. M. (1996). Power analysis and determination of sample size for covariance structure modeling. Psychological Methods, 1(2), 130-140. https://doi.org/10.1037/1082-989X.1.2.130

Midgley, D. F., \& Dowling, G. R. (1978). Innovativeness: The Concept and Its Measurement. Journal of Consumer Research, 4(4), 229. https://doi.org/10.1086/208701

Monroe, K. B. (1973). Buyers' Subjective Perceptions of Price. Journal of Marketing Research, 10(1), 70-80. https://doi.org/10.2307/3149411

Nelson, P. (1970). Information and Consumer Behavior. Journal of Political Economy, 78(2), 311-329. https://doi.org/10.1086/260231

Nelson, P. (1974). Advertising as Information. Journal of Political Economy, 82(4), 729-754. https://doi.org/10.1086/259630

Northen, J. R. (2000). Quality attributes and quality cues Effective communication in the UK meat supply chain. British Food Journal, 102(3), 230-245. https://doi.org/10.1108/00070700010324727

Park, C. W., \& Lessig, V. P. (1981). Familiarity and Its Impact on Consumer Decision Biases and Heuristics. 
Journal of Consumer Research, 8(2), 223-231. https://doi.org/10.1086/208859

Plummer, J. T. (1971). Life Style Patterns and Commercial Bank Credit Card Usage. Journal of Marketing, 35(2), 35-41. https://doi.org/10.2307/1249914

Reicks, A. L., Brooks, J. C., Garmyn, A. J., Thompson, L. D., Lyford, C. L., \& Miller, M. F. (2011). Demographics and beef preferences affect consumer motivation for purchasing fresh beef steaks and roasts. Meat Science, 87(4), 403-411. https://doi.org/10.1016/j.meatsci.2010.11.018

Robertson, T. S. (1967). The Process of Innovation and the Diffusion of Innovation. Journal of Marketing, 31(1), 14-19. https://doi.org/10.2307/1249295

Roehrich, G. (2004). Consumer innovativeness - Concepts and measurements. Journal of Business Research, 57(6), 671-677. https://doi.org/10.1016/S0148-2963(02)00311-9

Rogers, E. M. (2003). Diffusion of innovations (5th ed.).

Sijtsma, K. (2009). On the Use, the Misuse, and the Very Limited Usefulness of Cronbach. Psychometrika, 74(1), 107-120. https://doi.org/10.1007/s11336-008-9101-0

Steenkamp, J. B. E. M., ter Hofstede, F., \& Wedel, M. (1999). A Cross-National Investigation into the Individual and National Cultural Antecedents of Consumer Innovativeness. Journal of Marketing, 63(2), 55. https://doi.org/10.2307/1251945

Thu, T. T., Moritaka, M., \& Fukuda, S. (2016). The Study of Beef Market Structure and Channel Competition in Ho Chi Minh City, Vietnam. Journal of Faculty of Agriculture, Kyushu University, 61(2), 391-400.

Tuckman, B., \& Harper, B. E. (2012). Conducting Educational Research. Journal of Research in Music Education, 27. https://doi.org/10.2307/3344713

Urbany, J. J. E., Dickson, P. R. P., Wilkie, L., \& Wilkie, W. (1989). Buyer uncertainty and information search. Journal of Consumer Research, 16(2), 208-215. https://doi.org/10.1086/209209

Verbeke, W., \& Ward, R. W. (2006). Consumer interest in information cues denoting quality, traceability and origin: An application of ordered probit models to beef labels. Food Quality and Preference, 17(6), 453-467. https://doi.org/10.1016/j.foodqual.2005.05.010

Yuan, K. H. (2005). Fit indices versus test statistics. Multivariate Behavioral Research, 40(1), 115-148. https://doi.org/10.1207/s15327906mbr4001_5

\section{Copyrights}

Copyright for this article is retained by the author, with first publication rights granted to the journal.

This is an open-access article distributed under the terms and conditions of the Creative Commons Attribution license (http://creativecommons.org/licenses/by/4.0/). 